\title{
SLOBODA VJEROISPOVIJESTI U PRAKSI EVROPSKOG SUDA ZA LJUDSKA PRAVA I USTAVNOG SUDA CRNE GORE
}

\author{
UDK: $342.724(4)$
}

DOI: 10.31141/ZRPFS.2020.57.136.535

Izvorni znanstveni rad

Primljeno: 10. veljače 2019.

\begin{abstract}
Rad je posvećen tumačenju i primjeni jemstva zaštite slobode vjeroispovijesti u praksi Evropskog suda za ljudska prava i Ustavnog suda Crne Gore. U radu se određuje pojam slobode vjeroispovijesti i njeno ograničenje, istorijat dokumenata koji regulišu religijske slobode, kao apsolutno pravo koje pripada pojedincima i religijskim zajednicama. Navedena je recentna praksa Evropskog suda za ljudska prava vezano za položaj velikih crkava, manjih religijskih grupa, obreda, prozetizma i unutrašnje autonomije, kao i praksa Evropskog suda za ljudska prava o slobodi vjeroispovijesti pojedinca, koja pokazuje pozitivnu i negativnu stranu strazburške jurisprudencije i praksa Ustavnog suda Crne Gore u predmetima apstraktne kontrole i povodom ustavnih žalbi.
\end{abstract}

Ključne riječi: sloboda vjeroispovijesti, član 9. Evropske konvencije za zaštitu ljudskih prava, Evropski sud za ljudska prava, Ustav Crne Gore i Ustavni sud Crne Gore

\section{UVOD}

Sloboda vjeroispovijesti ili uvjerenja podrazumijeva pravo svakog da, postupajući po sopstvenoj savjesti, sam ili u zajednici s drugim, javno ili privatno ispoljava vjeru ili uvjerenje molitvom, propovijedima, običajima, obredom ili na drugi način, pravo da prihvati ili promijeni vjeru ili uvjerenje, slobodu da učestvuje u vjerskoj pouci i nastavi, ili pouci odnosno nastavi koji odgovaraju vlastitom uvjerenju, kao i pravo da njeguje i razvija vjersku tradiciju ili tradiciju u skladu s vlastitim uvjerenjem i pravo da odbije, u skladu sa zakonom, ispunjenje vojne ili druge obaveze koja uključuje upotrebu oružja. ${ }^{2}$

Riječ je o posebnoj vrsti prava koja se baziraju na moralu i pravdi, pa su u određenom smislu iznad države, ali s njenom obavezom da ih poštuje i štiti. ${ }^{3}$ Po svom značenju za najveći broj ljudi sloboda vjeroispovijesti je, i istorijski i u

1 Mr. Hamdija Šarkinović, sudija Ustavnog suda Crne Gore.

2 Jasna Omejec, Konvencija za zaštitu ljudskih prava i temeljnih sloboda, Strazburški acquis, Novi informator, Zagreb, 2014., str. 1044.

3 Neđo Milićević, „Sloboda vjere i vjeroispovijedanja“, Godišnjak Pravnog fakulteta u Sarajevu, XLVII-2004, str. 253. 
savremenom svijetu, postala univerzalna potreba i interes s karakteristikama koje omogućavaju veće prisustvo prava nego u slučaju pravnog tretmana slobode misli, savjesti i uvjerenja, u koju i sama ulazi. ${ }^{4}$ Sloboda vjeroispovijesti je čovjekovo prirodno pravo koje se ne može ograničavati pravnim normama, jer se radi o apsolutnom ljudskom pravu, zbog kojeg se on ne može kažnjavati i uznemiravati niti prisiljavati. Tretiranje ove slobode kao apsolutnog prava ima svoje praktične efekte koji se ogledaju u tome što ona može postati istinski vrijedna ukoliko se može slobodno izraziti; ako to nije moguće, u pitanju je pritisak na čovjeka da promijeni svoja uvjerenja, što znači da narušavanje slobode vjeroispovijesti postoji uvijek kad čovjek ne može da postupa u skladu sa svojim vjerskim uvjerenjima, uključujući i to da ih sam mijenja.

Sloboda vjeroispovijesti je čovjekova duhovna sfera, njegov forum internum, koja - za razliku od slobode misli i savjesti - ima i eksternu komponentu, forum externum, jer se ne može zamisliti pripadnost određenoj vjeri bez mogućnosti ispovijedanja vjere i drugim ljudima. Prava na slobodu misli, savjesti i vjeroispovijesti u velikoj se mjeri ispoljavaju unutar srca i uma pojedinca. Tek kad neko manifestuje sopstvene misli ili ubjeđenja, država postaje svjesna njihovog postojanja i karaktera. ${ }^{5}$

Augsburški mir (1555), zajedno sa Vestfalskim mirom (1648), koji se uzima kao početak novog doba, važni su dokumenti u razvoju religijskih sloboda u Evropi. Protestantska reformacija zaživjela je na mnogim njemačkim teritorijama koje su tada sačinjavale Sveto Rimsko Carstvo, pa je Augsburškim mirom izjednačen status luteranskih i katoličkih vladara u tadašnjoj Evropi i dopušteno da svjetovni vladari mogu odrediti koju religiju mogu usvojiti unutar svojih teritorija, po principu cuius regio, eius religio. ${ }^{6}$ To je bio značajan korak o napuštanju teorije o carstvu zasnovanoj na zajedničkoj religiji, premda je prihvatanje slobode religije još daleko. Podanicima katolicima i luterancima dato je pravo da se presele na teritoriju kneza čija im religija odgovara. Na teritoriji srednje i sjeverne Evrope odvijala se borba između katolika i protestanata, luteranaca i kalvinista. Oslabljene snage Carstva 1648. godine nagodile su se s protivnicima i zaključile vestfalske sporazume u Minsteru i Osnabriku, napokon sahranivši svoje pretenzije o carstvu koje je na okupu držala katolička vjera. ${ }^{7}$

U prošlosti su donošeni dokumenti od ustavnopravnog i međunarodnopravnog značaja da zaštite slobodu vjeroispovijesti, a pojedini su bili posljedica višedecenijskih vjerskih sukoba i revolucionarnih slobodarskih pokreta. Nanski edikt iz 1598. godine stavio je tačku na vjerske ratove u Francuskoj, a Vestfalski mirovni sporazum je okončao tridesetogodišnji rat katolika i protestanata u Evropi. Garantovanje slobode vjerovanja i uvjerenja nije izostalo ni u Virdžinskoj povelji o pravima iz 1776, niti u francuskim deklaracijama o pravima čovjeka i građanina iz

4 Ante Gavrić, „Crkva i pravo čovjeka“, Glas Koncila, br. 27, 1967.

Donna Gomien, Kratki vodič kroz Evropsku konvenciju o ljudskim pravima, Beograd, 1994., str. 52.

6 Gerhard Benecke, Germany in the Thirty Years War, London, Edwin Arnold, 1978., str. 8.

Malcolm D. Evans, Historijska analiza slobode religije ili uvjerenja kao tehnika rješavanja vjerskih sukoba, Centar za napredne studije, Sarajevo, 2015., str. 71. 
1789. i 1793. godine. Danas je sloboda misli, savjesti i vjeroispovijesti zajemčena na međunarodnom nivou Međunarodnim paktom o građanskim i političkim pravima (član 14) i Američkom konvencijom o ljudskim pravima (član 12), dok član 10 Povelje o osnovnim pravima Evropske unije preuzima formulaciju člana 9 Evropske konvencije za zaštitu ljudskih prava i osnovnih sloboda. ${ }^{8}$

Najvažnije aktivnosti Savjeta Evrope s obzirom na slobodu vjeroispovijesti i uvjerenja odnose se na tri pitanja: prvo je prigovor savjesti vojnoj službi, tj. pravo pojedinca da odbije vojnu službu na osnovu savjesti i da tim pojedincima dopuste da obavljaju alternativnu službu na ravnopravnoj osnovi ${ }^{9}$ druga grupa inicijativa odnosi se na ulogu religije u savremenom društvu, u kojem je naglašeno da je saradnja između religije i demokratije ne samo moguća već i neophodna: ${ }^{10}$ treće pitanje je rast i razvoj novih pokreta religijskog ili spiritualnog karaktera. ${ }^{11}$

Sloboda misli, savjesti i religije jeste pravo koje po prirodi pripada pojedincima, ali ono ima veoma značajnu institucionalnu ili „kolektivnu“ dimenziju, jer je u međunarodnom pravu duboko usađeno pravilo da svaka konfesija ima pravo na religijsku slobodu, bez obzira na to radi li se o tradicionalnoj velikoj crkvi ili skorašnjoj ili atipičnoj grupi, jer sve religijske denominacije moraju imati slobodu da djeluju neometano u svakoj zemlji bez neopravdanih ograničenja, čak i ako brane moralne vrijednosti koje su u opreci s vrijednostima koje prihvata određeno društvo, manifestuje sopstvene misli ili ubjeđenja, onda država postaje svjesna njihovog postojanja i karaktera. ${ }^{12}$

Ustav Crne Gore odredbama člana 46 garantuje pravo na slobodu misli, savjesti i vjeroispovijesti, a ostvarivanje slobode vjeroispovijesti i status vjerskih zajednica trenutno su propisani Zakonom o pravnom položaju vjerskih zajednica iz 1977. godine.

\section{PRAKSA EVROPSKOG SUDA ZA LJUDSKA PRAVA O SLOBODI VJEROISPOVIJESTI}

\section{Pravni okvir i značaj slobode vjeroispovijesti}

Odredbama člana 9 EKLJP propisano je, da ,svako ima pravo na slobodu misli, savjesti i vjere; ovo pravo uključuje slobodu da promijeni vjeru ili uvjerenje i slobodu da, sam ili zajedno sa drugima, javno ili privatno, ispoljava svoju vjeru ili uvjerenje molitvom, propovijedima, običajima i obredima“. Uslovi za ograničavanje ovog

8 Tanasije Marković, Sloboda misli, savesti i veroispovesti, Komentar Konvencije za zaštitu ljudskih prava i osnovnih sloboda, Službeni glasnik, 2017., str. 214-215.

9 Rezolucija Parlamentarne skupštine 337 (1967.) i Preporuka Komiteta ministara R (87)8 (1987.).

10 Preporuka Parlamentarne skupštine 1202 (1993.) o religijskoj toleranciji u demokratskom društvu i Preporuka Parlamentarne skupštine 1396 (1999.) o religiji i demokratiji i Preporuka Komiteta ministara R (97)21(1997.) zemljama članicama o medijima i promovisanju kulture tolerancije.

11 Preporuka Parlamentarne skupštine 1178 (1992.) o sektama i novim religijskim pokretima.

12 Donna Gomien, Kratki vodič kroz Evropsku konvenciju o ljudskim pravima, Beograd, 1994., str. 52. 
prava definisani su u članu 9 (2) EKLJP, koji propisuje da ,sloboda ispoljavanja svoje vjere ili uvjerenja podliježe samo onim ograničenjima koja su propisana zakonom i koja su neophodna u demokratskom društvu u interesu javne bezbjednosti, radi zaštite javnog poretka, zdravlja ili morala, ili radi zaštite prava i sloboda drugih“".

Prema jurisprudenciji Evropskog suda za ljudska prava izraženoj u presudi Velikog vijeća Bayatyan protiv Jermenije (2011) naznačen je okvir i značenje slobode vjeroispovijesti:

„118. Sud ponavlja da je sloboda mišljenja, savjesti i vjeroispovijesti, zajemčena članom 9 Konvencije, jedan od osnova 'demokratskog društva' u smislu Konvencije. Ta sloboda, u svojoj vjerskoj dimenziji (in its religious dimension), jedan je od najvažnijih elemenata koji stvaraju (go to make up) identitet vjernika i njihove koncepcije života, ali je takođe dragocjeno sredstvo ateista, agnostika i skeptika i onih koji prema vjeri nemaju nikakav odnos (the unconcerned). O njoj zavisi pluralizam, neodoljiv dio demokratskog društva, čije se ostvarenje skupo plaćalo vjekovima. Ta sloboda obuhvata, inter alia, slobodu prihvatiti ili ne prihvatiti vjerska uvjerenja (freedom to hold or not to hold religious beliefs) ili praktikovati ili ne praktikovati vjeru (practise or not to practise a religion)..."

Navedene slobode uživaju ne samo zaštitu člana 9 zasebno i u vezi s članom 11 nego i člana 6 Konvencije.

„35. ... član 9 mora se tumačiti u svijetlu člana 11 Konvencije, koji osigurava udruženi život (associative life) protiv neopravdanih miješanja države..." ${ }^{\text {"13 }}$

Evropski sud je utvrdio da su vjeroispovijesti koje uživaju zaštitu sve tradicionalne crkve i islamska zajednica, ali i vjerske zajednice novijeg doba, kao što su Jehovini svjedoci, ${ }^{14}$ Scijentološka crkva, ${ }^{15}$ Unifikacijska (Munova) $\mathrm{crkva}^{16}$ itd. Pod slobodom misli i vjeroispovijesti podrazumijeva se i pravo da se ne bude religiozan ili da se vjera ne ispovijeda. ${ }^{17}$

\section{Praksa Evropskog suda o slobodi vjeroispovijesti prema religijskim zajednicama}

Evropski sud u Strazburu je u svojoj jurisprudenciji utvrdio politička načela koja određuju odnos između države i religije, pri čemu je priznao da postoji određeno „područje diskrecione ocjene“ u pogledu načina na koje države strukturiraju svoje odnose s religijskim zajednicama. Različite forme saradnje između države i religijskih zajednica mogu postojati i u situacijama kada države ne sarađuju na strogo ravnopravnoj osnovi sa svim religijama, te se ravnopravnost (član 14 Evropske konvencije) mora primjenjivati rigorozno radi očuvanja religijskih

\footnotetext{
ECHR, presuda Fusu Arcadie i drugi protiv Republike Moldavije (2012.).

ECHR, presuda Thlimmenos protiv Grčke (2000.).

ECHR, presuda Scijentološka crkva Moskve (Church of Scientology Moscow) protiv Rusije (2007.).

16 ECHR, presuda Nolan i K. protiv Rusije (2009.).

17 ECHR, presuda Kokkinakis protiv Grčke (1993.).
} 
sloboda. Ni privilegovana saradnja između države i određenih crkava u formi skrivene konfesionalnosti države (Grčka) ili u formi državne crkve (Engleska $i$ neke skandinavske države) ne smatra se protivnom Evropskoj konvenciji. Prema shvatanju Suda, odnos privilegovane saradnje ne proizvodi za posljedicu značajan diskriminatorski uticaj na pojedince ili neopravdanu štetu za slobodu djelovanja koje ostale grupe i pojedinci moraju uživati u religijskim i ideološkim pitanjima, jer odredbe člana 9 Evropske konvencije imaju za cilj da pruže adekvatnu garanciju prava na slobodu vjeroispovijesti i uvjerenja, a ne da uspostave jedinstvene kriterijume za odnos između crkve i države u zemljama članicama Savjeta Evrope niti prinudno nametnu sekularizam. Stav države prema religiji je političko pitanje i rezultat je istorijske tradicije i društvenih okolnosti u svakoj zemlji. U slučaju Kokkinakis Sud nije doveo u pitanje blisku povezanost Grčke prvoslavne crkve s državom. Položaj velikih tradicionalnih crkava prema stavu Evropskog suda ima za cilj da zaštiti religiozna osjećanja njihovih vjernika pa je Sud u predmetima Otto-Preminger-Institut i Wingerove podržao odluku austrijskih i britanskih vlasti o zabrani komercijalne distribucije filmova koji su uvredljivi za hrišćansko stanovništvo.

Prema jurisprudenciji Evropskog suda za ljudska prava manje religijske grupe imaju pravo na istinsku slobodu da djeluju, a ne samo da budu tolerisane.

U predmetu Hoffman protiv Austrije Sud je zauzeo stav da nacionalni sud pri donošenju odluke o starateljstvu nad djecom u slučaju razvoda ne smije različito tretirati roditelje na osnovu religije. ${ }^{18}$ Pripadnici manjinskih religijskih grupa ne smiju biti podvrgnuti nadzoru ukoliko nema uvjerljivog opravdanja koje se zasniva na nečemu drugom osim njihove religijske pripadnosti. ${ }^{19}$ Međutim, Sud je u predmetu Chaare Shalom vs Tsedek usko tumačio princip ravnopravnosti, koji se ticao obrednog klanja životinja, prema kojem nacionalne vlasti uživaju prostor diskrecione ocjene u davanju određenih pravnih privilegija religijskim denuminacijama kada uređuju odnose s religijskim zajednicama, ukoliko nije dokazano da je narušena sloboda pojedinca da praktikuje svoju religiju. Sud je zauzeo stav da niti pravo na religijsku slobodu niti princip ravnopravnosti nijesu bili povrijeđeni činjenicom da su francuske vlasti dodijelile odobrenje za izdavanje administrativnih dozvola za obredno klanje isključivo Jevrejskom zbornom udruženju Pariza, uskraćujući ga manjinskom jevrejskom udruženju ultraortodoksne orijentacije.

Evropski sud je priznao pravo religijskim grupama da posjeduju i upravljaju vlastitim objektima za obavljanje obreda $i$ okupljanje. Uskraćivanje ovog prava bez dovoljnog opravdanja nije u skladu s Evropskom konvencijom, prema doktrini

18 Odluka je donesena shodno odredbama čl. 14 i 8 Konvencije (pravo na uživanje privatnog $\mathrm{i}$ porodičnog života). Jedna domaćica je konvertirala u Jehovine svjedoke i odvela djecu sa sobom još u toku trajanja razvoda braka. Evropski sud je poništio odluke austrijskih nacionalnih sudova koje su starateljstvo nad djecom dodijelili ocu.

19 Tsavachidis protiv Grčke, pred. br. 28802/95 odnosi se na nadzor nad Jehovinim svjedocima koje je vršila Nacionalna obavještajna služba. Okončan je prijateljskim rješenjem u kome se grčka vlada složila da plati određenu sumu novca za troškove i dostavila formalnu izjavu po kojoj „Jehovini svjedoci nijesu i neće biti u budućnosti podvrgnuti bilo kakvom praćenju zbog njihovih religijskih opredjeljenja“. 
Suda u slučajevima Manoussakis $i$ Penditis. ${ }^{20}$ Prozelitizam religijskih manjina je bio predmet interesovanja u dva predmeta protiv Grčke. U predmetu Kokkinakis Sud je smatrao da odredbe člana 9 Konvencije obuhvataju pravo pojedinca i religijskih grupa da šire svoje doktrine i pridobijaju svoje sljedbenike kroz prozelitizam, pod uslovom da se ne služe iskorišćavanjem, prevarnim ili nasilnim sredstvima. ${ }^{21}$

Pravo religijskih grupa da budu priznate i da imaju svoju unutrašnju autonomiju bilo je predmet jurisprudencije Evropskog suda za ljudska prava u predmetu Šerif, ${ }^{22}$ a u predmetu Crkva Besarabija Sud je ponovio principe iz prethodna dva navedena slučaja, pošto je vlada Moldavije odbila da dâ pravni subjektivitet crkvi tvrdeći da je riječ o šizmatičkoj grupi unutar Prijestone crkve Moldavije, koja je priznata zakonom.

\section{Sloboda udruživanja i sloboda vjeroispovijesti}

Odluka Evropskog suda u predmetu Refah Partisi (Refah partija) protiv Turske pokrenula je neka pitanja u vezi s budućom interpretacijom slobode udruživanja i slobode religije. Refah Partisi je bila politička partija sa specifično islamskim usmjerenjem iako je prihvatila načelo sekularizma. Zastupala je projekat promovisanja ,pluralnog pravnog sistema“ u zemlji, prema kojem bi svaka religijska grupa rukovodila posebnim religijskim pravilima. Turski Ustavni sud izveo je zaključak o postojanju skrivene agende same partije čiji je cilj bilo uspostavljanje političkog sistema koji nije u skladu ne samo s načelom lacizma nego i sa samim konceptom demokratije - naime, cilj im je bilo uspostavljanje teokratskog sistema utemeljenog na šerijatu ili islamskom pravu uz pribjegavanje, ako je neophodno, džihadu ili svetom ratu. Evropski sud je potvrdio odluku na koju je uložena žalba Velikom vijeću Evropskog suda, koje je podržalo raniju presudu i prihvatilo njene razloge.

Stav je Evropskog suda da pitanje vjere i njeno praktikovanje za koje nacionalne vlade smatraju da dotiče područje državne i nacionalne sigurnosti teško mogu biti razlog za opravdanje miješanja u član 9 Konvencije. Relevantni međunarodni standardi vezani za pojam ,državne sigurnosti“ sadržani su u Načelima iz Sirakuze o ograničenjima i ukidanju odredbi sadržanih u međunarodnom paktu o građanskim

20 U predmetu Manoussakis apelanti su tražili odobrenje vlade da uspostave obredno mjesto, a pošto odobrenje nije izdato u periodu koji su oni smatrali pretjerano dugim, počeli su koristiti to mjesto. Pokrenuti su krivični postupci protiv njih na grčkim sudovima. Evropski sud je utvrdio povredu člana 9 Evropske konvencije.

21 Sljedbenik Jehovinih svjedoka uhapšen je i kasnije osuđen od grčkih sudova shodno zakonu donešenom 1938. godine koji prozelitizam kvalifikuje kao krivično djelo. Sud je zaključio da grčka vlada nije obezbijedila dovoljno dokaza da je gospodin Kokkinakis, koji je samo propovijedao evangelizam od vrata do vrata, bio uključen u neprimjereni prozelitizam, čime je povrijeđena Konvencija.

22 Predmet se odnosio na imenovanje muslimanskog vjerskog vođe (muftije) u grčkoj regiji Trakiji, gdje je muftiju izabrala muslimanska zajednica ignorišući intervenciju državne vlasti koju propisuje grčki zakon o izboru i imenovanju muftije. Identični stav Sud je zauzeo u presudi Hasan i Čauš, koji se odnosi na spor dvije različite frakcije bugarske muslimanske zajednice i intervencije državne vlasti prilikom imenovanja muftije. 
i političkim pravima, koje je usvojilo Ekonomsko i socijalno vijeće Ujedinjenih nacija 1985. godine, koji glase:

„29. Za opravdanje ograničenja određenih prava može se pozvati na državnu sigurnost samo kad se ograničavanja uvode radi zaštite opstanka nacije i njenog teritorijalnog integriteta ili političke nezavisnosti protiv sile ili prijetnje silom.

30. Državna sigurnost ne može biti razlog za nametanje ograničenja radi sprečavanja lokalnih ili relativno izolovanih prijetnji redu i zakonu." ${ }^{\text {23 }}$

\section{Praksa Evropskog suda o slobodi vjeroispovijesti pojedinaca}

Kao i ostali međunarodni dokumenti o ljudskim pravima, i Evropska konvencija tretira slobodu misli, savjesti i religije kao pravo koje u prvom redu pripada pojedincima. Pravo religijskih grupa proističe iz prava pojedinaca, ali je individualna dimenzija ovog prava zanemarena i u jurisprudenciji Evropskog suda ima manju zaštitu u odnosu na korporativnu dimenziju ovog prava.

Nedovoljna zaštita individualne slobode religije ili uvjerenja javlja se iz terminologije koja je upotrijebljena u Evropskoj konvenciji i drugim međunarodnim dokumentima koji uređuju sadržaj slobode religije. Tako član 9(1) spominje pravo na iskazivanje religije ili uvjerenja obredima, poučavanjem, praksom i pridržavanjem. Prema tome, pojam prakse sadržan u članu 9 Konvencije garantuje pravo pojedincu da postupa u skladu sa zabranama i nalozima vlastite savjesti. Ova garancija treba biti pružena bez obzira na to jesu li ove prakse utemeljene na sadržajima institucionalne religije ili potiču iz strogo ličnih uvjerenja, (član 9 (2)) jer sloboda postupanja nije apsolutna. Ovakvo široko tumačenje prava na iskazivanje uvjerenja u praksi predložio je Opšti komentar člana 18 Međunarodnog pakta o ljudskim pravima Ujedinjenih nacija koji je usvojio Komitet za ljudska prava 1993. godine. Praksa Suda razlikuje unutrašnji aspekt religijske slobode koji podrazumijeva slobodu vjerovanja koja obuhvata slobodu izbora uvjerenja i slobodu promjene religije i spoljni aspekt slobode koji se sastoji od slobode iskazivanja religije ili uvjerenja. Prva dimenzija religijske slobode apsolutna je i ne smije biti ograničena, dok je sloboda iskazivanja religijskih uvjerenja relativna i može biti podvrgnuta ograničenjima koja su uređena članom 9(2) Konvencije. ${ }^{24}$

Javna vlast ne smije preduzimati niti dozvoljavati bilo kakvo direktno djelovanje s ciljem da se građani prisiljavaju da vjeruju ili ne vjeruju u nešto. U slučaju Kjeldsen Sud je mišljenja da državi, koja organizuje obrazovni sistem, nije

23 U predmetu Nolan $i$ K. protiv Rusije (2009.) Evropski sud je utvrdio da Rusija nije predočila nikakve dokaze u prilog tvrdnji da su aktivnosti misionara crkve negativno uticale na državnu sigurnost odnosno na prava drugih, pa je došlo do povrede člana 9 Konvencije.

24 Campbell $i$ Casans protiv Ujedinjenog Kraljevstva. U ovom predmetu dvije majke, podnositeljice zahtjeva, između ostalog su tvrdile da su njihova prava, zajemčena drugom rečenicom člana 2 Protokola br. 1 povrijeđena zbog kažnjavanja kao disciplinske mjere u školama koje su pohađala njihova djeca, pri čemu je Evropski sud morao razmotriti značenje sintagme „vjerskih i filozofskih uvjerenja“ roditelja iz druge rečenice član 2 Protokola 1.

Kokkinakis protiv Grčke, par. 31, 33. 
dopušteno da razvija bilo kakve aktivnosti koje bi značile indoktriniranje učenika u pogledu određenog religijskog ili moralnog svjetonadzora, suprotno ubjeđenju njihovih roditelja. ${ }^{25}$ U slučaju Buscarini Sud je podržao stav da se građanin ne smije prisiljavati da polaže zakletvu na jevanđeljima kao uslov za stupanje u javnu službu, što se može smatrati prisiljavanjem nekog da izrazi religijska uvjerenja suprotno svojoj volji. ${ }^{26}$ Esencijalno pitanje jeste razumijevanje relativnog karaktera slobode pojedinca da djeluju ili praktikuju naloge vlastite savjesti, što je usko povezano s pitanjem konflikata između prava i svijesti, između pravnih i moralnih dužnosti jer pojam praksa ne uključuje svako djelo koje je motivisano ili učinjeno pod uticajem religije.

Prema praksi strazburške jurisprudencije, određene profesionalne situacije koje su dobrovoljno prihvaćene mogu podrazumijevati specifična ograničenja religijske prirode, kao što je slučaj unutar ,sistema vojne discipline, koji po svojoj prirodi podrazumijeva mogućnost uspostavljanja ograničenja na neka prava i slobode pripadnicima oružanih snaga koja se ne smiju nametati civilima“". ${ }^{27} \mathrm{U}$ jurisprudenciji Evropskog suda često nailazimo na praksu da Sud pravi razliku između aktivnosti država, koje imaju direktan ili indirektan uticaj na slobodu vjeroispovijesti kada se ponašanje pojedinca sprečava ili sankcioniše zakonom ili drugom vrstom aktivnosti države koja direktno ima za cilj da ograniči iskazivanje vjere, obavljanje obreda ili širenje određenih ili svih religija. U ovim slučajevima Konvencija zahtijeva da država opravda miješanje u individualnu slobodu shodno članu 9(2), a naročito da dokaže da su ograničavajuće mjere „neophodne u demokratskom društvu“. Sud je zauzeo ovaj pristup u predmetima Kokkinakis i Buscarini, a sličan zaključak je izveo i u predmetu Dahlab kad je ocijenio neprihvatljivom apelaciju švajcarske učiteljice u javnoj osnovnoj školi, preobraćenice u islam, kojoj je primjenom kantonalnog zakona koji ima za cilj da sačuva sekularni karakter javnih škola bilo zabranjeno da nosi tradicionalno propisanu maramu na glavi kad predaje svojim učenicima. ${ }^{28}$

25 Kjeldsen, Buck Madsen i Pedersen protiv Danske. Radilo se o implementaciji novog Sistema seksualnog obrazovanja u javnim školama koji je imao za cilj da spriječi neželjene trudnoće među tinejdžerima. Neki roditelji su zastupali prigovor savjesti prema ovoj nastavi smatrajući da je seksualno obrazovanje u isključivoj nadležnosti roditelja. Danska vlada je odbila da djecu tih roditelja oslobodi časova seksualnog obrazovanja. Kjeldsen je bio prvi slučaj o kome je sud odlučio a koji se odnosio na religijska uvjerenja, a odluka se tumačila na osnovu člana 2 Prvog protokola (Pravo na obrazovanje i pravo roditelja u pogledu obrazovanja njihove djece).

26 Buskarini $i$ dr. protiv San Marina. Sud je potvrdio da nije u skladu s Evropskom konvencijom lišavanje dvoje izabranih članova Parlamenta njihove službe u slučaju da ne polože zakletvu na jevanđeljima, jer bi to bilo ,ravno zahtjevu dvojici izabranih predstavnika naroda da polože zakletvu vjernosti određenoj religiji“, par. 39.

27 Kalac protiv Turske.

28 Dahlab protiv Švajcarske, odluka o prihvatljivosti 42393/98, 2001. 


\section{PRAKSA USTAVNOG SUDA CRNE GORE U PREDMETIMA SLOBODE VJEROISPOVIJESTI}

\section{Ustavna i zakonska određenja prava na slobodu vjeroispovijesti u Crnoj Gori}

Ustav Crne Gore garantuje pravo na slobodu misli, savjesti i vjeroispovijesti u članu 46 stav 1, koji propisuje: „Svakome se jemči pravo na slobodu misli, savjesti i vjeroispovijesti, kao i pravo da promijeni vjeru ili uvjerenje, i slobodu da, sam ili u zajednici sa drugima, javno ili privatno, ispoljava vjeru ili uvjerenje molitvom, propovijedima, običajima ili obredom“. Prema stavu 2 ovog člana niko nije obavezan da se izjašnjava o svojim vjerskim ili drugim uvjerenjima. Stav 3 se odnosi na ograničenja slobode ispoljavanja vjerskih uvjerenja i navodi da se sloboda ispoljavanja vjerskih uvjerenja može ograničiti samo ako je to neophodno radi zaštite života i zdravlja ljudi, javnog reda i mira, kao i ostalih prava zajemčenih Ustavom. Odredbama člana 14 navodi se da su ,vjerske zajednice odvojene od države" i garantuju svim vjerskim zajednicama jednaka prava i slobode u vršenju vjerskih obreda i vjerskih poslova, a odredbama člana 50 nadležni sudovi mogu spriječiti širenje informacija i ideja putem sredstava javnog obavještavanja radi sprečavanja propagiranja rasne, nacionalne i vjerske mržnje ili diskriminacije.

Ostvarivanje slobode vjeroispovijesti i status vjerskih zajednica trenutno su propisani zakonom o pravnom položaju vjerskih zajednica iz 1977. godine. ${ }^{29}$ Ovaj zakon predviđa pravni i regulatorni okvir za osnivanje i ukidanje vjerskih zajednica, sadrži pravila o mjestima i prostorima gdje se mogu vršiti vjerski obredi i definiše okvir za osnivanje vjerskih škola.

Predlog zakona o slobodi vjeroispovijesti ili uvjerenja i pravnom statusu vjerskih zajednica $^{30}$ usaglašen je s važećim međunarodnim dokumentima i sa Smjernicama za zakonodavno preispitivanje zakona koji utiču na vjeroispovijest i uvjerenja. ${ }^{31}$ Međutim, u javnosti su se pojavila oprečna mišljenja između predlagača zakona i Srpske pravoslavne crkve u vezi s odredbama čl. 62 i 63 Predloga zakona, vezano za rješavanje imovine vjerskih zajednica nastalih prije 1. decembra 1918. godine, a tiču se imovine koja predstavlja kulturnu baštinu.

Predlogom navedenog Zakona predviđa se:

„Vjerski objekti i zemljište koje koriste vjerske zajednice na teritoriji Crne Gore koji su izgrađeni, odnosno pribavljeni iz javnih prihoda države ili su bili u državnoj svojini do 1. decembra 1918. godine, i za koje ne postoje dokazi o pravu svojine vjerskih zajednica, kao kulturna baština Crne Gore, državna su svojina.

29 Sl. list SRCG 9/77, 26/77, 29/89, 39/89, Sl. list RCG 27/94, 36/03.

30 Predlog zakona o slobodi vjeroispovijesti ili uvjerenja i pravnom položaju vjerskih zajednica uradilo je Ministarstvo za ljudska i manjinska prava, dostavljen je Vladi Crne Gore aktom 04-090-593/194, 14. maja 2019. godine. www.minmanj.gov.me.

31 CDL-AD(2004)028. 
Vjerski objekti koji su izgrađeni na teritoriji Crne Gore zajedničkim ulaganjima građana do 1. decembra 1918. godine, a za koje ne postoje dokazi o pravu svojine, kao kulturna baština Crne Gore, državna su svojina." (čl. 62)

„Organ uprave nadležan za poslove imovine dužan je da, u roku od godinu dana od dana stupanja na snagu ovog zakona, utvrdi vjerske objekte i zemljište koji su, u smislu člana 62 ovog zakona, državna svojina, izvrši njihov popis i podnese zahtjev za upis prava državne svojine na tim nepokretnostima u katastar nepokretnosti.

Organ uprave nadležan za poslove katastra je dužan da upis prava iz stava 1 ovog člana izvrši u roku od 60 dana od dana podnošenja zahtjeva."

Prema mišljenju Evropske komisije za demokratiju kroz pravo (Venecijanske komisije) dato na navedeni Predlog zakona ${ }^{32}$ navedene su „odredbe i njihova činjenična pozadina prilično neprecizni i nejasni“".

Prema Međunarodnom izvještaju o vjerskim slobodama za 2017. godinu koji objavljuje Ministarstvo vanjskih poslova SAD (Department of State) ${ }^{33}$ oko 72 odsto stanovništva je pravoslavne vjere. Lokalni mediji procjenjuju da Srpskoj pravoslavnoj crkvi pripada oko 70 odsto pravoslavnog stanovništva, dok Crnogorska pravoslavna crkva predstavlja preostalih 30 odsto. Popis stanovništva navodi da 19,1 odsto stanovništva čine muslimani, 3,4 odsto rimokatolici, a 1,2 odsto su ateisti. Pored toga, 2,6 odsto ispitanika nije dalo odgovor, a nekoliko ostalih grupa, uključujući adventiste sedmog dana (registrovane lokalno kao Hrišćanska adventistička crkva), budiste, Jehovine svjedoke, druge hrišćane i agnostike, zajedno čine manje od 1 odsto stanovništva. Jevrejska zajednica ima oko 350 pripadnika.

Potpisani su „Osnovni sporazumi“ između Vlade Crne Gore i niza vjerskih zajednica, kojima se definiše pravni status relevantne vjerske zajednice i uređuju odnosi tih zajednica s državom. Prvi temeljni sporazum odnosio se na Svetu Stolicu i potpisan je 2011. godine. Nakon toga su, 2012. godine, uslijedili Sporazum koji uređuje međusobne odnose između Vlade i Islamske zajednice i Sporazum koji uređuje međusobne odnose između Vlade i Jevrejske zajednice. Dosad nije potpisan sličan sporazum sa Srpskom pravoslavnom crkvom ili Crnogorskom pravoslavnom crkvom.

\section{Praksa Ustavnog suda Crne Gore o slobodi vjeroispovijesti u predmetima apstraktne kontrole}

2.1. Odlukom Ustavnog suda Republike Crne Gore U br 33/2000 i 36/2000 od 12. maja 2003. godine utvrđeno je da odredbe člana 13 Zakona o položaju vjerskih zajednica (,Službeni list SR Crne Gore“, br. 9/77) nijesu u saglasnosti s Ustavom Crne Gore.

32 CDL-AD(2019)010, Mišljenje br. 953/2019, Strazbur, 24. jun 2019. godine.

33 Ministarstvo vanjskih poslova SAD (Department of State), Kancelarija za demokratiju, ljudska prava i rad, Međunarodni izvještaj o stanju vjerskih sloboda za 2017. - Crna Gora. 
„Osporenim odredbama člana 13 Zakona se prema mišljenju Suda ograničava, odnosno zabranjuje vjenčanje i krštenje po vjerskom obredu prije zaključenja braka i upisa djeteta u matičnu knjigu rođenih pred nadležnim državnim organima, odnosno propisuju uslovi za mogućnost obavljanja vjerskih obreda vjenčanja i krštenja novorođenog djeteta, čime se ograničava vjerska zajednica (crkva) da na zahtjev građanina (vjernika) slobodno izvrši vjerski obred vjenčanja i vjerski obred krštenja novorođenog djeteta prije ili nezavisno od zaključenja braka i upisa djeteta u matičnu knjigu rođenih kod nadležnih državnih organa. Time se, istovremeno, po ocjeni Ustavnog suda, ograničava sloboda vjeroispovijesti, koja se prije svega sastoji u vjerskom ubjeđenju i praktikovanju vjere. Obaveza države je da u pogledu poštovanja i zaštite osnovnih ljudskih prava, koja se odnose na slobodu vjeroispovijesti, obezbijedi slobodno polje za ispoljavanje vjere, vjerskog ubjeđenja i za mogućnost da se ono slijedi u načinu života, u funkcionisanju vjerskih zajednica kao i slobodno polje za odbacivanje religije i za poštovanje ćutanja o vjerskom ubjeđenju, tako da se slobodno mogu formirati i razviti razna shvatanja i da se samim tim može slobodno i svjesno razviti individualno ubjeđenje, jer proklamovana sloboda vjeroispovijesti zahtijeva slobodan izbor svakog građanina."

2.2. Rješenjem Ustavnog suda Republike Crne Gore U br. 33/2000 i 36/2000 od 15. marta 2003. godine nije prihvaćena inicijativa za ocjenjivanje ustavnosti odredaba člana 2 istog zakona, povodom inicijative upravne radnje Ministarstva unutrašnjih poslova - Odjeljenja bezbjednosti Cetinje, kojom je ovaj organ izdao uvjerenje na osnovu kojeg je konstatovano osnivanje vjerske zajednice Crnogorske pravoslavne crkve.

„Naime, iz Ustava Republike Crne Gore proizilazi da se slobode i prava ostvaruju na osnovu Ustava, a da se način ostvarivanja sloboda i prava čovjeka i građanina može propisati zakonom u skladu sa Ustavom, kada je to neophodno za njihovo ostvarivanje. Saglasno tome, Republika je ovlašćena da u cilju obezbjeđenja ravnopravnog položaja vjeroispovijesti, slobode vjerovanja, javnog i privatnog ispovijedanja vjere, zakonom uredi osnovna pravila koja su primjenjiva na sve religije i crkve, pravila koja se uklapaju u okvir neutralnog zakonskog poretka, koja treba da obezbijedi punu slobodu vjeroispovijesti. Propisivanjem obaveze prijavljivanja osnivanja ili prestanka rada vjerske zajednice, sadržaja prijave i određivanjem da vjerske zajednice imaju svojstvo građanskog pravnog lica, zakonodavac, po ocjeni Ustavnog suda, nije povrijedio ustavom utvrđene principe o odvojenosti vjeroispovijesti od države o ravnopravnosti vjeroispovijesti o slobodi vjeroispovijesti u uređivanju svoje unutrašnje organizacije i vjerskih poslova. Ovi principi nijesu povrijeđeni ni time što je osnivač vjerske zajednice Zakonom obavezan da osnivanje ili prestanak rada vjerske zajednice, odnosno njenog organa i organizacije, prijavi organu uprave nadležnom za unutrašnje poslove, tj. državnom organu, s obzirom da taj organ ne daje odobrenje za njihovo osnivanje ili prestanak rada, već samo vodi evidenciju tih činjenica. Pri tom je zakonodavac samostalan u ocjeni kojem će organu povjeriti evidentiranje odnosnih činjenica, pa ovaj Sud nije nadležan da ocjenjuje cjelishodnost zakonskog rješenja u tom dijelu.“ 
2.3. Ustavni sud Republike Crne Gore je odlukom U. br. 48/05 od 13. septembra 2005. godine utvrdio da odredbe člana 10 stav 2 u dijelu koji glasi: „krsna slava“ Statuta Opštine Herceg Novi (,Službeni list Republike Crne Gore - opštinski propisi“, br. 15/04) i Odluka o utvrđivanju krsne slave Opštine Herceg Novi (,Službeni list Republike Crne Gore - opštinski propisi““, br. 38/04), koju je donijela Skupština Opštine Herceg Novi, na sjednici od 18. novembra 2004. godine, nijesu u saglasnosti s Ustavom i zakonom i prestaju da važe danom objavljivanja date odluke.

„Polazeći od ustavnog principa da su građani jednaki bez obzira na bilo kakvu posebnost ili lično svojstvo i s tim u vezi da ih niko ne može dovoditi u stuaciju da vjera ili drugo ubjeđenje budu razlog odvajanja, nerazumijevanja i razlikovanja, po ocjeni Suda, Skupština opštine je osporenim aktima uvela svetkovanje krsne slave, čime je povrijedila ustavni princip iz člana 34 Ustava, kojim se jamči sloboda ubjeđenja, savjesti i misli. Skupština opštine Herceg Novi je ovakvim propisivanjem uvela vjerske običaje u državne i druge institucije na području opštine Herceg-Novi i tome povrijedila ustavni princip odvojenosti crkve od države (član 11 Ustava). Takođe, Ustavni sud je utvrdio da je Skupština opštine Herceg Novi postupila i suprotno odredbi člana 23 Zakona o lokalnoj samoupravi, jer nije dobila od Vlade Republike Crne Gore saglasnost na odredbe Statuta kojima se uređuje, između ostalog, i praznik."

2.4. Ustavni sud Crne Gore u odluci U-II br. 56/4 od 24. februara 2017. godine nije prihvatio inicijativu za pokretanje postupka za ocjenu ustavnosti i zakonitosti odredbe člana 14 stav 1 Ugovora o uređenju odnosa od zajedničkog interesa između Vlade Crne Gore i Islamske zajednice u Crnoj Gori, broj 01-427, od 30. januara 2012. godine, koji su zaključile Vlada Crne Gore i Islamska zajednica u Crnoj Gori.

„Osporenom odredbom člana 14 stav 1 Ugovora, po ocjeni Ustavnog suda, vjerniku (pripadniku islamske zajednice u Crnoj Gori) omogućeno je da, ukoliko to želi, javno ispolji nacionalnu pripadnost, vjeroispovijest ili običaj nošenjem kape ili marame kao sastavnim dijelom nošnje (...) u postupcima pred državnim organima, kao i u sistemu obrazovanja, ako je riječ o učeniku i studentu. Na taj način, po ocjeni Ustavnog suda, donosioci akta su osporenim odredbama člana 14 st. 1 Ugovora, u suštini, pripadnicima Islamske zajednice u Crnoj Gori omogućili ispoljavanje vjerskih osjećanja (nošenje kape ili marame) bez ograničenja, odnosno da zbog ispoljavanja vjerskih osjećanja ne budu neposredno ili posredno diskriminisani prilikom zaposlenja, kao zaposleni, u postupku pred državnim organima, pai u sistemu obrazovanja, kao učenici i studenti, Zakona o manjinskim pravima i slobodama, kojim je propisano da manjinski narodi i druge manjinske nacionalne zajednice i njihovi pripadnici imaju pravo izražavanja, čuvanja, razvijanja i prenošenja i javnog ispoljavanja nacionalnog, etničkog, kulturnog, vjerskog i jezičkog identiteta, kao dijela njihove tradicije. Ustavni sud je stoga ocijenio da donosioci Ugovora osporenom odredbom člana 14 stav 1 nijesu prekoračili svoja ustavna i zakonska ovlašćenja. Takođe, osporenom odredbom člana 14 stav 1 Ugovora, po nahođenju Ustavnog suda, nije povrijeđeno ni načelo legaliteta iz odredbe člana 145 Ustava, kako u pogledu formalne, tako i u pogledu materijalne zakonitosti. 
Navod podnosioca inicijative ,da je osporenom odredbom člana 14 stav 1 Ugovora omogućeno religijsko djelovanje u sistemu obrazovanja“ Ustavni sud je ocijenio neosnovanim, jer iz odredbe člana 5, člana 5a stav 1 i člana 19 Opšteg zakona o vaspitanju i obrazovanju proizilazi da se „svjetovnost“ obrazovanja i vaspitanja i zabrana religijskog djelovanja, u smislu tog zakona, odnose na sadržinu obrazovnog ili javno važećeg obrazovnog programa čije se sprovođenje vrši u javnim ustanovama koje nijesu licencirane kao srednje vjerske škole, a ne na ispoljavanje vjerskih osjećanja učenika koji stiču obrazovanje na osnovu tih programa.“

\section{Praksa Ustavnog suda u odnosu na pojedinačne pravne akte}

Ustavni sud Crne Gore je u svom radu imao samo jedan predmet u vezi sa slobodom vjeroispovijesti, povodom ustavne žalbe, Už-III br. 201/13 od 29. decembra 2016. godine, u kojem je Radović Risto - Amfilohije Radović, mitropolit crnogorsko-primorski Srpske pravoslavne crkve u Crnoj Gori oglašen krivim:

„Zato što je dana 06, 13. i 18. januara 2011. godine u Podgorici i Baru, na javnom mjestu govorom povrijedio nacionalna i vjerska osjećanja građana na način što je 06. januara u Baru ispred Hrama Svetog Jovana Vladimira prilikom obraćanja pravoslavnim vjernicima na ceremoniji polaganja badnjaka proklinjanjem svakog ko bi se usudio da sruši Crkvu Svete Trojice na Rumiji riječima: 'Bog ga srušio, i njega i njegovo potomstvo, časni krst mu sudio', za lidera Demokratskog saveza Albanaca u Crnoj Gori Mehmeda Bardhija izjavio da poziva na novi turski rat i da 'nije dobar znak i moram da pomenem po imenu da gospodin Bardhi koji je musliman neprestano podstiče bezumne ljude da urade isto ono što su uradili Turci osvajači kada su osvojili Bar i kada su srušili časni krst na Rumiji', dok je u Podgorici istog dana oko 17:30 časova, ispred Hrama Hristovog Vaskrsenja pravoslavnim vjernicima i javnosti obratio se riječima: 'jer šta je drugo kad se čuje iz usta nekoga koji kaže da je hrišćanin, pri tom kaže još i da je mitropolit, pa kaže treba srušiti Crkvu Svete Trojice na Rumiji, samo pasja vjera i lažna vjera može tako govoriti pored Ćivota Svetog Petra Cetinjskog', a dana 13. januara u Podgorici oko 16:00 časova pred Crkvom Svetog Đorđa prilikom dočeka Nove godine po julijanskom kalendaru crnogorski jezik nazvao 'čirgilica', dok je 18. januara pozvao na vjerski sukob riječima: 'ukoliko dođe do rušenja crkve to može izazvati neke od džamija, da ne kažem krvoprolića na vjerskoj osnovi', te tako vrijeđanjem, omalovažavanjem i izražavanjem prezira povrijedio vjerska i nacionalna osjećanja građana, čime je počinio prekršaj iz čl. 17 st.1 Zakona o javnom redu i miru, i izrečena mu je opomena. ${ }^{\text {"34 }}$

"Podnosilac ustavne žalbe se pozvao na povredu prava na slobodu misli, savjesti i vjeroispovijesti iz odredbe člana 46 Ustava i člana 9 Evropske konvencije, tvrdeći da je osporenim odlukama podnosiocu povrijeđeno pravo na vjeroispovijest,

34 Vijeće za prekršaje Crne Gore rješenjem PŽP br. 3000/12-8 od 19. XII. 2012. godine odbilo je žalbu i potvrdilo prvostepeno rješenje. 
budući da je u bogoslužećem kontekstu ispovijedao vjeru pravoslavnim vjernicima. Podnosilac tvrdi da samo ljudi opterećeni ideološkim predrasudama i mržnjom u odnosu na one koji drugačije misle i govor mogu ovo proglasiti za ,jezik mržnje“.

Ustavni sud je većinom glasova stao na stanovište da ,član 9 Konvencije ne štiti svako djelo podstaknuto i nadahnuto religijom ili vjerovanjem (presuda Kalac protiv Turske), od 1. jula 1997. Evropski sud smatra da u demokratskom društvu u kom $\mathrm{u}$ istom stanovništvu istovremeno postoji nekoliko religija, ponekad je potrebno ograničiti ovu slobodu da bi se uskladili interesi raznih grupa i osiguralo poštovanje svake vjere (presuda Kokkinakis, stav 33).“

\section{ZAKLJUČAK}

Praksa Evropskog suda za ljudska prava u presudama religijske slobode u kojima je odlučivao pokazuje pozitivnu stranu davanjem naglasaka na ideju da ustupanje privilegija velikim crkvama mora biti praćeno priznanjem i stvarnom zaštitom prava religijskih manjina. Saradnja države s crkvama može se javiti u različitim vremenima, ali sloboda koju uživaju religijske grupe i njihovi sljedbenici mora se razumjeti u skladu sa strogom ravnopravnošću. Negativna strana strazburške sudske prakse jeste sklonost ka pridavanju apsolutne nadmoći „neutralnim“ zakonima nad pravima individualne svijesti, čije posljedice su štetne za pojedince i za manjinske religijske grupe koje zastupaju moralne vrijednosti koje ne korespondiraju u potpunosti zapadnom nasljeđu, tj. vrijednostima judeo-hrišćanske tradicije združenim sa drugim vrijednostima koje su karakteristične za sekularizam. Praksa Ustavnog suda Crne Gore, u domenu slobode vjeroispovijesti, iako skromna, saglasna je s praksom Evropskog suda za ljudska prava. 


\section{FREEDOM OF RELIGION IN THE PRACTICE OF THE EUROPEAN COURT OF HUMAN RIGHTS AND CONSTITUTIONAL COURT OF MONTENEGRO}

This paper discusses issues concerning the concept of freedom of religion that is defined by the Constitution of Montenegro and the European Convention for the Protection of Human Rights and Fundamental freedoms. It is a specific type of right that is based on morality and justice, which is above the state, but with its obligation to respect and protect it. This is people's natural right that cannot be restricted by legal norms, because it is an absolute human right, in other words its people's spiritual sphere, its forum internum, which has an external component, externum forum. The European Court found that the confessions that enjoy the protection are: all traditional churches and Muslim communities but also religious communities of recent times, Jehovah's Witnesses, Church of Scientology, the Unification (Moon's) church, etc. Paper quotes the most recent jurisprudence of the European Court of Human Rights regarding the situation of large churches, small religious groups, rituals, proselytism and internal autonomy, as well as the case law of the European Court of Human Rights on freedom of religion of the individual and the jurisprudence of the Constitutional Court in the cases of the abstract control and constitutional complaint.

Key words: freedom of religion, article 9 of the European Convention for the protection of human rights, European court of Human Rights, the Constitution of Montenegro, The Constitutional Court of Montenegro. 